\section{Populismin syvintä olemusta etsimässä}

Herkman, Juha (2019). Populismin aika. Vastapaino. 204 sivua.

POPULISMIN AIKA perehdyttää lukijan kiinnostavaan, poikkitieteelliseen aihealueeseen, josta ei aiemmin ole Suomessa kirjoitettu akateemisia teoksia. Teoksessa tuodaan esille erilaisia populismiin liittyviä näkökulmia ja tutkimusta.

Populismi on ajankohtainen ja kiinnostava ilmiö, jota Herkmaninkin mukaan käsitellään usein poliittisena ilmiönä. Käsittelyssä korostuvat populismin sen suhde mediaan ja mediasuhteiden hyödyntäminen oman sanoman esilletuomisessa.

Mutta populismia voidaan tarkastella laajemminkin. Politiikantutkimuksen ohella populismia voidaan tutkia muun muassa kulttuurintutkimuksen tai viestinnän näkökulmasta, yhdistyyhän siihen ilmiön rakentuminen tietyssä ympäristössä tiettynä aikana. Politiikan lisäksi ilmiöitä rakentuu vaikkapa talouden tai urheilun piirissä.

On ristiriitaista, että populismin suosio kasvaa ja laajenee, vaikka ihmiset ovat entistä medialukutaitoisempia. Suuren yleisön kuvittelisi näkevän ja ymmärtävän mediaviestien taustat ja syttyvän uudenlaiseen liikehdintään hyvin varovaisesti. Herkman kuitenkin osoittaa, että on käynyt päinvastoin.

Populismin vastakkainasettelun avulla tunnutaankin siis etsittävän huonolle vaihtoehdolle parempaa, tutustumatta kovin- kaan syvällisesti sen paremman vaihtoehdon tarjoamaan sisältöön. Herkman mainitsee, että erityisesti kaksi asiaa - brittien brexit ja Donald Trumpin valinta Yhdysvaltain presidentiksi - ovat innoittaneet useita tutkijoita teeman pariin.

\section{POPULISMIN JA IDEOLOGIAN SUHTEESTA}

Jotkut kansalaiset vieroksuvat vahvasti populistisia liikkeitä. Jopa tutkimuksessa populismi saattaa olla negatiivisesti värittynyt käsite. Siihen sisältyy usein ajatus kansan kahtiajaosta ja jonkin ihmisryhmän poissulkemisesta. Usein populistisiin liikkeisiin yhdistyy jonkinlainen nostalgia, jolloin niissä ei nähdä kehittymisnäkökulmaa. Paikoin niitä pidetään pelkästään pelottavina ääriliikkeinä.

Herkman pohtii muun muassa populismin suhdetta ideologiaan. Jos ideologia määritellään ihmisten käyttäytymistä ohjaavaksi ajatusten ja kokemusten järjestelmäksi, lukeutuuko protestiluonteinen, vastakkain asetteleva ja retoriikkaa hyödyntävä sekä ymmärrystä tietyllä tavalla rajaava populismi ideologiaksi? Kysymykseen on vaikea löytää yksiselitteistä vastausta.

Herkman näkee populismin syntyvän usein poliittisesta kriisitilanteesta tai yhteiskunnan raken-

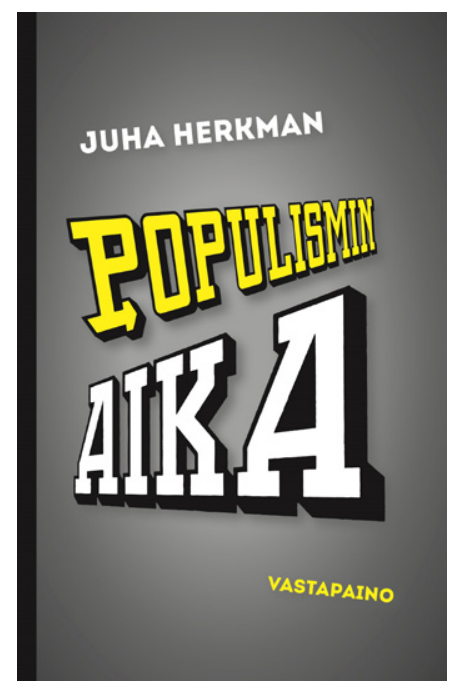

nemuutoksesta. Sillä saattaakin olla osuutensa esimerkiksi puolueiden syntyprosessissa tai taistelussa rakennemuutosta vastaan.

Populistista liikettä saatetaan pitää vastavoimana ei toivotulle kehityssuunnalle. Liikkeet kiinnostavat usein niitäkin, joita politiikka sinällään ei välttämättä kiinnosta. Mukaan lähdetään joissain tapauksissa enemmän mielikuvien kuin todellisen tiedon perusteella.

Populistisen liikkeen henkilöityminen on kiinnostava yksityiskohta: käytännössä moni kiinnittyy pikemminkin henkilöön kuin liikkeeseen. Henkilökulttiin sisältyy vahvasti esiintymisen ja mediajulkisuuden merkitys. Monet suositut populistisen liikkeen keulakuvat voivat olla taitavia, ja mediajulkisuutta käytetään tarkoituksellisesti hyväksi. Asian voi nähdä niinkin, että populistinen liike edellyttää syntyäkseen vahvan keulakuvan ja mediaosaamisen.

Populismin ja demokratian 


\section{POPUlismi ON AIKAAMME KUULUVAA VALTIOIDEN JA}

\section{RYHMITTYMIEN V ̈̈LIST ̈̈ INFORMAATIOTAISTELUA.}

suhde on kiinnostava. Populismia voidaan pitää osana demokraattista järjestelmää, mutta sitä on myös pidetty demokraattisen kehityksen vastavoimana ja esteenä.

\section{SÄHKÖINEN MEDIA APUNA ILMIÖIDEN RAKENTAMISESSA}

Mikä sitten tekee populismista juuri nyt ajankohtaisen käsitteen? Sen voi sanoa valtavirtaistuneen. Sähköisessä mediassa tieto leviää nopeasti, ja sosiaalinen media on sopiva kasvualusta populismille. Uusia ilmiöitä on mahdollista rakentaa jopa tarkoituksellisesti.

Sosiaalisessa mediassa on helppo rakentaa kuvaa kansan suvereniteetista, ihmisten itsemäräämisoikeudesta, jossa kuka vain voi esiintyä unohdetun kansan puhemiehenä. Näin saattaa syntyä eliitin vastainen kampanja, joka tuottaa yhteenkuuluvuutta ja mahdollistaa valtaapitävien voimakkaankin arvostelun.

Populistinen liike rakentuukin lähinnä vallan vastaliikkeeksi vahvan ja aktiivisen johtajan avulla. Pieni vähemmistö saattaa näin käyttää äänekkään enemmistön ääntä mediaa hyödyntäen ja luoda mielikuvan siitä, että äänessä on enemmistö. Enemmistöajatus on todellisuudessa usein illuusio, ja näkyvä ryhmä vain pieni osa kansaa. Siitäkin on kuitenkin esimerkkejä, että liike lopulta saavuttaa paljon kannattajia.

Herkman toteaa, että hyvinvointivaltio, globalisaatio ja postmoderni kulttuuri mahdollistavat populismin. Hän kutsuukin postmodernin aikaa samalla populismin ajaksi. Kirjan sisältämät käytännön esimerkit havainnollistavat teorian käytäntöön.

Populismiin liittyy olennaisena kaksoispuhe: omassa ryhmässä kielenkäyttö on usein radikaalimpaa kuin julkisuudessa. Näin siihen saattaakin käytännössä liittyä jopa ääriliikehdintä.

Populismia voidaan pitää aikaamme kuuluvana valtioiden ja ryhmittymien välisenä informaatiotaisteluna, jolla tavoitellaan itselle mahdollisimman suotuisaa mielipideilmastoa ja pyritään samalla vahingoittamaan vastapuolen yhtenäisyyttä.

Populistinen liikehdintä ei kuitenkaan jatku ikuisesti popu- listisena, vaan aktiivista liikehdintää seuraa yleensä tasapainoinen tila. Sen jälkeen seuraavasta uudesta kriisistä syntyy jälleen uudenlainen populistinen liike.

Herkman avaa kiinnostavalla tavalla ajankohtaista ilmiötä ja sen taustoja. Tausta juontaa juurensa yhteiskuntatieteellisestä tieteenalasta, mutta kirjaa voi suositella varsin laajalle lukijakunnalle. Populismia on vaikea asettaa yhden tieteenalan raameihin, eikä se ole edes tarkoituksenmukaista. Ilmiö koskee kansalaisia laajasti ja sitä voidaan tarkastella useista tulokulmista.

Etenkin julkisen työkentän toimijoiden, kuten opettajien, kannattaa tutustua kirjaan. Sujuvasti kirjoitettuna ja helppotajuisena akateemisena teoksena se sopii kenelle tahansa omasta ajankuvasta ja sen ilmiöistä kiinnostuneelle.

HELI ANTILA

YTM, KM, EO, lehtori

Tampereen ammattikorkeakoulu 